\title{
MELACAK JEJAK PENSYARAHAN KITAB HADIS
}

\author{
Sandi Santosa \\ Institut PTIQ Jakarta \\ Jalan Batan 1 No. 2 lebak Bulus, Cilandak Jakarta Selatan 12440, Indonesia \\ E-Mail:Sandisantosa@gmail.com
}

\begin{abstract}
All Muslims have received understand that the hadith Muhammad Saw is a way of life that is the primary after the Koran . Human behavior is not defined and the laws are still common then no detail later verses of the Koran , then let the solution sought in tradition. And as the Prophet has been around since the beginning of the development of Islam is a fact that can not be doubted. Because the cause and explanation of the hadith is always interesting to be in line with the development of the human mind is increasingly critical. And no wonder then that many parties joined in criticizing the hadith even though they do not understand the science. In this paper the author will explain about Sharh al - hadith, fiqh al - hadith, and the historical development of syarh hadith from time to time.
\end{abstract}

Keywords: hadis; syarah; critique; history; development.

\begin{abstract}
Abstrak
Seluruh umat Islam telah menerima paham, bahwa hadis Rosulullah Saw. itu sebagai pedoman hidup yang utama setelah al-Quran. Tingkah laku manusia yang tidak ditegaskan dan hukum-hukum yang masih bersifat umum yang kemudian tidak ada perincian setelahnya dari ayat-ayat al-Quran, maka hendaklah dicari penyelesaiannya di hadis. Dan hadis nabi telah ada sejak awal perkembangan Islam adalah sebuah kenyataan yang tidak dapat diragukan lagi. Karena itu sebab dan penjelasan tentang hadis selalu menarik untuk dikaji sejalan dengan perkembangan nalar manusia yang semakin kritis. Dan tidak heran jika kemudian banyak pihak yang ikut nimbrung dalam mengkritik hadits meskipun mereka tidak faham ilmunya.Dalam makalah ini penulis akan memaparkan tentang syarh al-hadis, fiqh al-hadits, serta sejarah perkembangannya.
\end{abstract}

Kata Kunci: hadis; kritik; perkembangan; sejarah; syarah.

\section{A. PENDAHULUAN}

Memahami sabda Rasulullah Saw, diperlukan penjelasan-penjelasan terhadap teks-teks (matan ) tersebut. Dalam berbagai kitab hadis yang telah dikumpulkan, memang terdapat matan yang mudah difahami, tapi tidak sedikit yang harus diberikan penjelasan. Namun demikian, baik matan itu mudah untuk diintrepretasikan, tetap saja memerlukan penjelasan untuk dapat dipahami maksudnya bagi setiap orang. Upaya untuk memberikan penjelasan inilah yang kita kenal dengan syarh al-hadis.

Syarh, dalam bahasa arab diambil dari kata syaraha - yasyrahu, syarhan. Ibn Zakaria menjelaskan bahwa kata tersebut (syaraha - yasyrahu ) terdiri dari sy, ra, dan ha, yang merupakan kata murni memiliki pemaknaan sebagai pembuka dan penjelas. ${ }^{1}$

${ }^{1}$ Abi al-Husain Ahmad Faris bin Zakaria, Mu'jam Al-Maqayis Fi Al-Lughah, ed. by Abdussalam Muhammad Harun (Beirut: Darr al-Fikr, 1979), juz3, 269. Penjelasan senada dijelaskan oleh ibn Mandzhur
Jika melihat definisi yang dibangun berdasarkan penjelaan ibn Zakaria atau ibn Mandzur, maka syarh al-hadis layaknya tafsir al-Qur'an, yaitu mempunyai tujuan sebagai penjelas terhadap hal-hal yang belum jelas. Oleh karenanya, dilihat dari segi maksud dan fungsionalnya, syarh dan tafsir mengandung arti dan maksud yang sama.

\section{B. PEMBAHASAN}

\section{Sejarah (Periodisasi) Syarh al-Hadis}

Untuk memahami bagaimana periodisasi sejarah perkembangan hadis, maka ada dua pandangan dalam membagi periodisasi, yaitu periodisasi ala Prof. Harun Nasution yaitu:

Pertama, periode klasik, yaitu zaman pertumbuhan dan kemajuan yang dialami ummat Islam. Periode ini dimulai sejak

dalam Lisan al-Arab bahwa al-Syarh adalah alKasyfu, al-Fathu, al-Bayan, dan al-Fahmu, Muhammad bin Mukrim bin Mundzir al-Afriqiy AlMasriy, Lisan Al-Arab (Beirut: Darr фadr), jilid. 4, 2228. 
zaman Nabi Muhammad sampai dengan tahun $1250 \mathrm{M}$.

Kedua, periode pertengahan, yaitu periode tahun $1250-1800 \mathrm{M}$.

Ketiga, periode modern (reformasi ), yaitu periode kebangkitan ummat Islam, yang melahirkan ide-ide pembaharuan. Periode ini dimulai pada tahun $1800 \mathrm{M}$ sampai dengan seterusnya.

Berdasarkan dua teori di atas, jika kita mendasarkan kepada kemunculan syarh, dari mulai yang sangat sederhana, dimana syarh diposisikan sebagai penjelas dan pemberi pemahaman terhadap sabda Rasulullah Saw, maka akan terlihat bahwa pen-syarh-an atas sabda Rasulullah, sudah dimulai sejak nabi Muhammad Saw 'memproduksi' sabdanya. Hal ini setidaknya bisa kita lihat dari beberapa sabda yang diucapkan Rasulullah Saw.

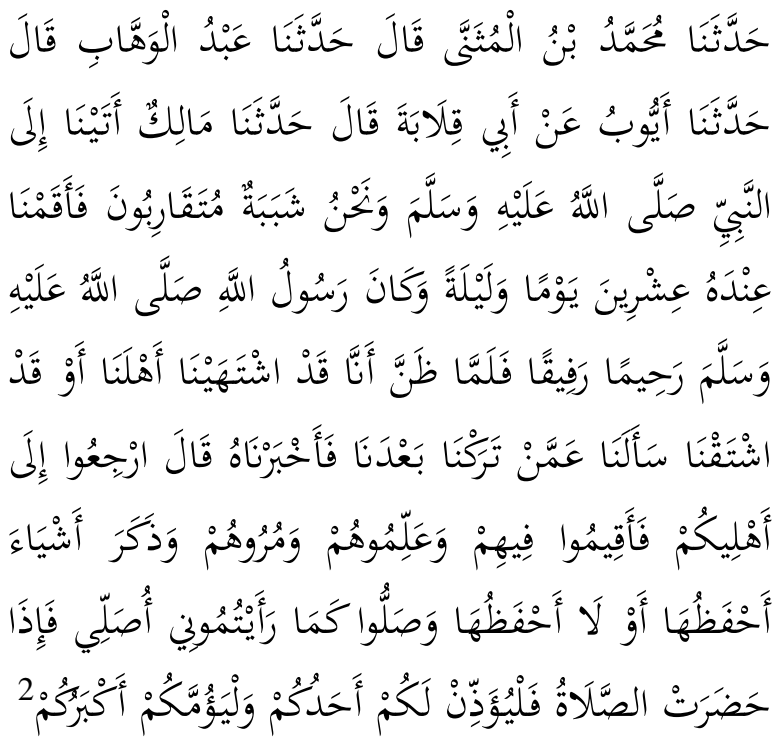

Telah menceritakan kepada kami Muhammad ibn Al Musanna berkata, telah menceritakan kepada kami 'Abdul Wahhab berkata, telah menceritakan kepada kami Ayyub dari Ab-Qilabah berkata, telah menceritakan kepada kami Malik, "Kami datang menemui Nabi Saw, saat itu kami adalah para pemuda yang usianya sebaya. Maka kami tinggal bersama beliau selama dua puluh hari dua puluh malam. Beliau adalah seorang yang

${ }^{2}$ Muhammad bin Isma'il Abu Abdullah AlBukhori, Al-Jami' Al-Shohih Al-Bukhori AlMukhtasar, ed. by Musthafa Dib (Beirut: Darr Ibnu Katsir, 1987), Juz. 1, 226. sangat penuh kasih dan lembut. Ketika beliau menganggap bahwa kami telah ingin, atau merindukan keluarga kami, beliau bertanya kepada kami tentang orang yang kami tinggalkan. Maka kami pun mengabarkannya kepada beliau. Kemudian beliau bersabda: "Kembalilah kepada keluarga kalian dan tinggallah bersama mereka, ajarilah mereka dan perintahkan (untuk shalat)". Beliau lantas menyebutkan sesuatu yang aku pernah ingat lalu lupa. Beliau mengatakan: "Shalatlah kalian seperti kalian melihat aku shalat. Maka jika waktu shalat sudah tiba, hendaklah salah seorang dari kalian mengumandangkan adzan, dan hendaklah yang menjadi Imam adalah yang paling tua di antara kalian".

Hadis di atas, merupakan hadis yang diungkapkan Rasulullah dihadapan para sahabat. Oleh karenanya, Mustafa as-Siba'i sebagaimana dikutip Mo Isom Yoesqi ${ }^{3}$ menyebut sebagai cara penyampaian contoh langsung dengan perbuatannya. Oleh karenanya, melihat kalimat yang diberikan Rasulullah tentang bagaimana shalat adalah mengikuti 'peragaan'4 yang dilakukan Rasulullah Saw itu sendiri, yang kemudian dipraktekkan oleh para sahabat.

Menelusuri jejak syarh berdasarkan hadis di atas, maka kita dapat memahami bahwa secara lisan, syarh sudah dilakukan oleh Rasulullah Saw sejak beliau mengucapkan sabdanya. Begitu pula 'pola' syarh setelah masa nabi, yaitu pada zaman sahabat, pola yang hampir sama dilakukan oleh para Sahabat Rasululla Sahabat mempunyai peranan yang amat penting, karena merekalah yang hidup pada masa nabi, langsung berinteraksi dengan sumber pertama. Maka wajar jika para sahabat adalah 'prototive' syarih terhadap sabda-sabda Rasulullah Saw.

Usaha untuk mengurai mata rantai pensyarh-an kitab hadis, dan atas dasar keterkaitan obyek kajian, maka uraian jejak

\footnotetext{
${ }^{3}$ Mo Isom Yoesq, Inklusivitas Hadits Nabi Muhammad Saw Menurut Ibn Taimiyah (Jakarta: Pustaka Mapan, 2006), 41.

${ }^{4}$ Definisi hadis yang dibangun oleh para ulama adalah segala sesuatu yang disandarkan kepada Nabi, baik perkataan, perbuatan, takrir (pengakuan ) dan segala keadaan beliau.
} 
syarh terhadap kitab-kitab hadis tidak bisa dipisahkan dari sejarah pembukuan hadis itu sendiri. Namun demikian, tidak selalu alur sejarah pengumpulan hadis, sebanding lurus dengan alur pensyarahan terhadap kitab hadis tersebut. Oleh karena itu, pemakalah berusaha mengurai kronologis sejarah pembukuan hadis dan kemudian menghadirkan jejak pen-syarh-an terhadap kitab-kitab hadis.

Padaperide awal digambarkan beberapa catatan yang menguraikan bahwa dokumentasi hadis 'tak resmi' telah dilakukan sejak masa Rasulullah Saw. Kemudian dilanjutkan dengan masa Sahabat. Di antara 'catatan tak resmi' yang berhasil terditeksi adalah al-sahifah al-sadiqah yang ditulis oleh ibn Lua'y ibn Ghalib al-Qurasiy al-sami (w. $63 \mathrm{H} \mathrm{).}{ }^{5}$ al-sahifah 'Ali ibn Abi Talib dan al-sahifah al-Jami'ah karya Imam Ali ibn Abi Talib ' (w. 40 H ). Kitab al-Faraid, karya Zaid ibn Tsabit al-Khazraji $(45 \mathrm{H})$. Sahifah hasan ibn 'Ali, karya alHasan ibn Ali ibn Abi Talib (w. $50 \mathrm{H}$ ). Sahifah Jabir ibn Abdillah, karya Abdillah Jabir ibn Abdillah al-Madani (w. $78 \mathrm{H}$ ). Nuskhah Samurah ibn Jundub, karya Samurah ibn Jundub ibn Hilal al-Fazari (w. $58 \mathrm{H}$ ). Kitab dan Mushaf Fatimah alZahra, karya Fatimah binti Ras-lillah Saw (w. $11 \mathrm{H}),{ }^{6}$ dan lain sebagainya.

Pada fase selanjutnya, dokumentasi atas hadis dilakukan kemudian oleh para Tabi'in. di antara berapa dokumen yang terditeksi adalah,

a. Sahifah Sa'id ibn Jubair (w. $95 \mathrm{H}$ ).

b. Sahifah Sulaiman ibn Qais al-Yask-ri (w. $75 \mathrm{H}$ ).

c. Sahifah Muhammad ibn Ali ibn Abi Talib (w. $81 \mathrm{H}$ ). ${ }^{7}$

d. sahifah Hammam ibn Munabih (w. $131 \mathrm{H}) .^{8}$

\footnotetext{
${ }^{5}$ Saifuddin, Tadwin Al-Hadis: Kontribusinya Dalam Perkembangan Historiografi Islam (Banjarmasin: Antasari Press, 2008), 143.

${ }^{6}$ Saifuddin, 145-154.

${ }^{7}$ Saifuddin, 145-154.

${ }^{8}$ Subhi Shalih, Ulum Al-Hadits $W a$ Musthalahuhu (Beirut: Dar Al-Ilmu Li al-Malayin, 1988), 31.
}

Pada masa tabi'in pula, dikenal dengan pendokumentasian hadis secara resmi yang dilakukan atas 'perintah' khalifah Umar ibn Abdil Aziz dan diaplikasikan oleh ibn Syihab al-Zuhri ( w. $124 \mathrm{H}$ ). ${ }^{9}$ Hingga akhirnya pada masa atba' al-tabi' in berkembanglah pendokumentasian hadis dengan sistematika yang lebih baik dari sebelumnya.

Puncak perkembangan tadwin kitab hadis adalah dengan lahirnya karya-karya yang disusun secara sistematis dan dengan usaha memilah antara 'ucapan' Rasulullah, sahabat, dan tabi'in. Di antara kitab hadis yang lahir pada fase ini, antara lain adalah sahih alBukhari, ${ }^{10}$ sahih Muslim, ${ }^{11}$ Sunan AbDaud, ${ }^{12}$ Sunan Nasa $i,{ }^{13}$ Sunan Tirmizi, ${ }^{14}$ dan Sunan Ibn Majah ${ }^{15}$

${ }^{9}$ Penulis menganggap tidak perlu berpanjang lebar menggambarkan kronologis perintah khalifah tentang pengumpulan hadis, ataupun masalah yang berkaitan di dalamnya. Lebih lanjut lihatMuhammad Mustafa Azhami, Hadis Nabawi Dan Sejarah Kodifikasinya (Jakarta: Pustaka Firdaus, 1994),106.

${ }^{10}$ Sahihal-Bukhari disusun oleh Ab- Abdullah Muhammad ibn Ismail ibn Ibrahim ibn al-Mughirah ibn Bardibah al-Ju'fi al-Bukhari (194-256 H ). Nama lengkap dari kitab ini adalah al-Jami' al-Musnad alSahihal-Mukhtasar min Umur Rasulilah Sallallahu 'Alaihi wa Sallam wa Sunanihi wa Ayyamihi. Kitab ini disusun berdasarkan sistematika fiqh, terdiri dari 97 judul bab, dengan 4550 sub bab. Lebih lanjut silahkan merujuk Saifuddin,184. Indal Abror, Kitab AlSahihal-Bukhari, Dalam Studi Kitab Hadis (Yogyakarta: Teras, 2003), 40-45.;Muhammad Muhammad Abu Syuhbah, Fi Rihab Al-Sunnah: AlKutub Al-Sahhah Al-Sittah (kairo: Majmu al-Buhus alIslami, 1969),57.

11 Sahih Muslim disusun oleh Ab- al-Husain Muslim bin al-Hajjaj bin Muslim ibn Kausyaz alQusyairi al-Naisab-ri (204-261 H ). Nama lengkap kitabnya adalah Al-Musnad al-Sahihal-Mukhtasar min al-Sunan bi al-Naql al-'Adl 'an al-'Adl 'an Ras-lillah Saw. Kitab ini disusun dengan sisitematika fiqh, dengan 54 bab. Lebih lanjut silahkan merujuk Saifuddin, 185-186.; Dadi Nurhaedi, SahihMuslim Dalam Studi Kitab Hadis (Yogyakarta: Teras, 2003),61-67.; Muhammad Muhammad Abu Syuhbah, 85-87.

12 Sunan Abu-Daud disusun oleh Abu Daud Sulaiman ibn al-'Asy'ats ibn Ishaq ibn Basyir ibn Syidad ibn Imran al-Azdi al-Sijistani (202-275 H ). Sistematika pembahasan dalam kitab ini disusun berdasarkan klasifikasi fiqh dengan 40 judul bab. Lebih lanjut silahkan merujuk Saifuddin, 186-187.; Suryadi, Sunan Abu Daud Dalam Studi Kitab Hadis (Yogyakarta: Teras, 2003), 85-93.; Muhammad Muhammad Abu Syuhbah, 109-110. 
Dari data yang penulis kumpulkan, terlihat bahwa pen-syarh-an hadis sudah dimulai sejak tahun 186 Antara lain Abdullah ibn Nafi al-Mash-r al-Saigh (w. 186 ) yang mensyarah kitab al-Muwatha, dengan judul Tafsir fi al-MuwaTa. Lalu Abu Marwan Abdul Malik ibn hubaib ibn Sulaiman alQurtubi al-Maliki (w. $237 \mathrm{H} \quad)^{16}$ terhadap kitab al-MuwaTa dengan judul Tafsir alMuwaTa. ${ }^{17}$

Pen-syarh-an kitab hadis, diikuti kemudian oleh Al-Imam Abi Sulaiman hamad ibn Muhammad al-Khitabi al-Busti (w. $388 \mathrm{H}$ ) yang men-syarh kitab sahih al-

13 Sunan Nasa' $i$ disusun oleh Ahmad ibn Syu'aib ibn Ali ibn Sinan ibn Bahr ibn Dinar (AbAbdurrahman al-Nasa'i $(215-303 \mathrm{H})$. Judul awal kitab ini adalah al-Mujtaba', namun lebih dikenal dengan sebutan Sunan Nasa'i. kitab ini disusun dengan sistematika fiqh, dengan 51 judul bab. Lebih lanjut silahkan merujuk Saifuddin, 189.; Afdawiza, Sunan Nasa'i Dalam Studi Kitab Hadis (Yogyakarta: Teras, 2003),130.; Muhammad Muhammad Abu Syuhbah, 132.

14 Jami' al-Tirmizi disusun oleh Ab- 'sa Muhammad ibn 'sa ibn Samurah ibn M-sa ibn al alSulami al-B-gi al-Tirmizi (209-279 H ). Kitab ini banyak dikenal dengan Sunan al-Tirmizi. Padahal nama asli kitabnya adalah al-Jami' al-Mukhtajar min al-Sunan 'an Ras-lillah Sallallahu 'Alaihi wa Sallam wa Ma'rifat al-Sahihwa al-Ma'lul wa Ma 'alaihi al'Amal. Kitab ini disusun dengan sistematika fiqh, terdiri dari 46 judul kitab. Lebih lanjut silahkan merujuk Saifuddin,187.; Suryadi, Jami' Al-Tirmidzi Dalam Studi Kitab Hadis (Yogyakarta: Teras, 2003), 104-105.; Muhammad Muhammad Abu Syuhbah, 116.

15 Sunan Ibn Majah disusun oleh AbAbdullah Muhammad ibn Yaid ibn Majah al-Rubay'iy al-Qazwaini (209 - $273 \mathrm{H})$. kitab sunannya disusun dengan sistematika fiqh, dengan 32 judul bab. Saifudin, Ibid., 189; M. Alfatih Suryadilaga, Sunan Ibn Majah Dalam Studi Kitab Hadis (Yogyakarta: Teras, 2003), 160 dan 170.; Muhammad Muhammad Abu Syuhbah, 137-138.

${ }^{16}$ Al-Maula Mustafa ibn Abdillah al-Qustantani al-Rumi al-Hanafi, Kasyfu Al-Fun-n 'an Asami AlKutub Wa Al-Funun (Beirut: Dar al-Fikr, 1994), vol 2. 724.

${ }^{17}$ Catatan Maulana Muhammad Zakaria alKandahlawi dua kitab ini tidak terditeksi keberadaannya, dan setelah kedua kitab tersebut, muncul Muhammad bin Sahn-n (w. 256). Namun kitab syarh yang ditulis oleh Sahn-n tidak terditeksi namanya . Lihat lebih lanjut Maulana Muhammad Zakaria al-Kandahlawi, Aujazu Al-Masalik Ila Muwatta Malik (Beirut: Dar al-Fikr), vol. 1, 48.
Bukhari dengan judul A'lam al-Sunan. Juga, al-Khitabi men-syarh Sunan Ab- Daud dengan nama Ma'alim al-Sunan. ${ }^{18}$

Jika kita melihat data di atas, maka usaha pen-syarh-an kitab hadis sudah dimulai dari: menurut Prof. Harun Nasution-, periode klasik, yaitu pada masa sebelum tahun 590 Selain beberapa syarh di atas, dalam kurun waktu hingga tahun $590 \mathrm{H}$, terungkap beberapa kitab syarh, diantaranya adalah alNama' fi Syarh al-MuwaTa karya Ahmad ibn Nasr al-Daudi al-Sadi (Ab- Ja'far ) (w.402 H ); Syarh sahih al-Bukhari li Ibn alBaTal karya Ab- al-hasan Ali ibn Khalaf ibn Abdi al-Malik (w. $449 \mathrm{H}$ ); ${ }^{19}$ Al-Tamhid Lima fi al-MuwaTa min al-Ma'ani wa alAsanid dan al-Taqsid fi Ikhtisar al-MuwaTa Bayan Musnad al-MuwaTa wa Mursalihi karya Al-Hafidz Ab- Amru Y-suf ibn Abdullah ibn Muhammad ibn Abdi al-Barr al-Andal-si al-Qurtubi al-Maliki (w. $463 \mathrm{H}$ ); Al-Muntaqa Syarh MuwaTa Imam Malik dan Al-Istifa'u fi Syarh al-MuwaTa ${ }^{20}$ karya AlQadhui Abu al-Walid Sulaiman ibn Khalaf ibn Sa'ad ibn Ayy-b al-Baji (w. $474 \mathrm{H}$ ). ${ }^{21}$ Kemudian Al-Qadhui Iyad ibn M-sa alYahsabi al-Maliki (w. $544 \mathrm{H}$ ) ${ }^{22}$ dengan syarhnya terhadap sahih Muslim dengan nama Al-Ikmal bi Fawaid Syarh Muslim; ${ }^{23}$

${ }^{18}$ Al-Khittabi men-syarh pertama kali terhadap Sunan Abu Daud, Ma'alim al-Sunan dan telah terbukukan dalam 4 jilid. Sedangkan untuk A'lam alSunan, syarh beliau terhadap Sahihal-Bukhari kemungkinan tidak selesai. Hal ini dikarenakan tidak dapat terditeksi diberbagai sumber. Lebih lanjut lihat Al-Maula Mustafa ibn Abdillah al-Qustantani al-Rumi al-Hanafi, Kasyfu Al-Fun-n 'an Asami Al-Kutub Wa Al-Funun (Beirut: Dar al-Fikr, 1994), Juz 1, 430-431. Khusus Ma'alim al-Sunan, data fisik terdapat di perpustakaan UIN Alauddin Makassar dengan spesifikasi 2 jilid (perjilid 2 juz ), penerbit Darul Fikr Beirut, terbit tahun 1991.

${ }^{19}$ Data fisik versi PDF dengan spesifikasi 11 jilid, penerbit Maktabah al-Rusyd Riyadh, tanpa tahun.

20 Data fisik terdapat di perpustakaan UIN Alauddin Makassar dengan spesifikasi 7 jilid, penerbit Darul Fikr Beirut, terbit tahun 1983.

${ }^{21}$ Maulana Muhammad Zakaria al-Kandahlawi, 46-47.

${ }^{22}$ Al-Maula Mustafa ibn Abdillah al-Qustantani al-Rumi al-Hanafi, juz 1, 440.

${ }^{23}$ Data fisik versi PDF dengan spesifikasi 8 jilid, penerbit Darul Wafa', terbit tahun 1998. 
al-Qadhui al-hafidz Abu Bakar Muhammad Ibn al-Arabi (w. $546 \mathrm{H}$ ), dengan syarhnya al-Qabas fi Syarh MuwaTa' Malik, ${ }^{24}$ dan alhafidz Ab-Bakar Muhammad ibn Abdillah al-Isbili (Ibnu al-Arabi al-Maliki (w.546 H ) dengan syarhnya terhadap Sunan al-Tirmizi dengan judul ${ }^{2}$ ridhuatu al-Ahwazi fi Syarh alTirmizi. ${ }^{25}$

Usaha pen-syarh-an hadis makin marak dilakukan pada zaman pertengahan, tepatnya selepas tahun $590 \mathrm{H}$ hingga 1179 pada periode ini, setidaknya lahir beberapa syarh terhadap kitab-kitab hadis, utamanya adalah terhadap kitab hadis al-Sittah dan MuwaTa Imam Malik. Usaha pensyarahan hadis terhadap kitab-kitab hadis diantaranya adalah terhadap sahih al-Bukhari lahir al-Kawakib al-Darari Syarh sahih al-Bukhari (sahih alBukhari bi Syarh al-Kirmani $)^{26}$ karya alAllamah Syamsuddin Muhammad ibn Yusuf ibn Ali al-Kirmani (w.796 H ), Fathu al-Bari Syarh sahih al-Bukhari ${ }^{27}$ karya al-Imam alhafidz Abi al-Fadl Ahmad ibn Ali ibn Muhammad ibn Muhammad ibn hajar alAsqalani (773-852 H ), Umdatu al-Qari ${ }^{28}$ karya al-Allamah Syeikh Badruddin Abi Muhammad Mahmud ibn Ahmad al-Aini alHanafi (w.762-855 H ), Irsyadu al-Syari ila sahih al-Bukhari ${ }^{29}$ karya al-Allamah Syeikh Sihabuddin Ahmad ibn Muhammad alKhatib al-Misri al-Syafi'i (dikenal alQastalani ) (851-923 H ), dan Jauharu alBukhari bi Syarh al-Qastalani karya Mustafa Muhammad Ammarah (?)

${ }^{24}$ Maulana Muhammad Zakaria al-Kandahlawi, 48.

25 Al-Maula Mustafa ibn Abdillah alQustantani al-Rumi al-Hanafi, Juz 1, 441-442. Data fisik versi PDF dengan spesifikasi 12 jilid, penerbit Darul Kutub al-'Ilmiyah Beirut, tanpa tahun.

${ }^{26}$ Data fisik versi PDF dengan spesifikasi 25 jilid, penerbit Darul Ihya al-Turas al-Arabi Beirut, tahun 1981

27 Data fisik terdapat di perpustakaan UIN Alauddin Makassar dengan spesifikasi 13 jilid, penerbit Darul Ma'rifah Beirut, tanpa tahun.

28 Data fisik terdapat di perpustakaan UIN Alauddin Makassar dengan spesifikasi 25 jilid, penerbit Darul Fikr Beirut, tanpa tahun.

29 Data fisik terdapat di perpustakaan UIN Alauddin Makassar dengan spesifikasi 15 jilid, penerbit Darul Fikr Beirut, terbit tahun 1990.
Syarh terhadap sahih Muslim, diantaranya adalah sahih Muslim bi Syarh alNawawi (al-Minhaj Syarh Shahih Muslim ) ${ }^{30}$ karya Muhyiddin Yahya ibn Syarf ibn Marra ibn hasan ibn husain ibn hizam al-Nawawi al-Syafi'i (w. $676 \mathrm{H}$ ), Mukhtasar sahih Muslim bi Syarh al-Nawawi karya Syeikh Syamsuddin Muhammad ibn Yusuf alQunawi al-Hanafi (w.788 H ), Ikmal Ikmal al-Mu'allim karya Muhammad ibn alKhalfah al-Wastani al-Ubay (w.827 H ), Mukammil Ikmal al-Ikmal karya al-Imam Muhammad ibn Muhammad ibn Yusuf alSan-si al-hasani ( w. $895 \mathrm{H}$ ), ${ }^{31}$ dan al-Dibaj 'ala sahih Muslim ibn al-Hajjaj ${ }^{32}$ karya alhafidz Jalaluddin ibn Abdirrahman ibn Abi Bakar al-Suyuti (w. $911 \mathrm{H}$ ). ${ }^{33}$

Syarh terhadap Sunan Abu Daud diantaranya adalah Talkhis Ma'alim al-Sunan diberi judul Ajalatu al-`im min Kitabi alMu'allim karya al-Allamah Abî al-Tayyib Muhammad Syamsu al-haq al-Azhim al‘badi (w.765 H ), Aunu al-Ma'bud 'ala Sunan Abu Daud karya Syeikh Syarafatu alhaq Muhammad al-Syaraf ibn 'Ali Haidar alsiddiq al-Azim al-Abadi (w.1319 ), dan Syarh Sunan Abi Daud al-Imam Abu Muhammad Mahmud ibn Ahmad bin Musa Badruddin al-Aini (w.855 H ). ${ }^{34}$

Syarh terhadap Sunan Ibn Majah diantaranya adalah Ma Tamas ilaihi al-Hajah ila Sunan Ibn Majah karya Syirajuddin Umar ibn Ali ibn al-Mulqin al-Syafi'i (w. 804 H ); Syarh al-Dibaj karya Syeikh Kamaluddin Muhammad ibn M-sa al-Damiri al-Syafi'i

30 Data fisik terdapat di perpustakaan UIN Alauddin Makassar dengan spesifikasi 10 jilid, penerbit Darul Ma'rifah Beirut, terbit tahun 1996.

${ }^{31}$ Untuk dua kitab ini, Ikmal Ikmal al-Mu'allim dan Mukammil Ikmal al-Ikmal dicetak dalam satu kitab. Data fisik terdapat di perpustakaan UIN Alauddin Makassar dengan spesifikasi 10 jilid, penerbit Darul Kutub al-Ilmiyah Beirut, terbit tahun 1994.

32 Data fisik versi PDF dengan spesifikasi 8 jilid, penerbit Dar ibn 'Affan Saudi Arabia, terbit tahun 1996.

${ }^{33}$ Muslim ibn al-Hajjaj, Al-Dibaj 'ala Sahih Muslim Ibn Al-Hajjaj (Saudi Arabia: Dar ibn 'Affan, 1996), Juz 1,440-441.

${ }^{34}$ Data fisik versi PDF dengan spesifikasi 7 jilid, penerbit Maktabah al-Rusyd 'Affan Riyadh, terbit tahun 1999. 
(w. $808 \mathrm{H} \mathrm{);} \mathrm{Misbah} \mathrm{al-Zujajah} \mathrm{'ala} \mathrm{Sunan}$ ibn Majah karya al-Hafîdz Jalaluddin ibn Abdirrahman ibn Abi Bakar al-Suyuti (w. 911 H ), dan Syarh Sunan Ibn Majah karya Muhammad Abd al-Hadi al-Sindi (w. 1038 H ). Namun, selain kitab tersebut di atas, Sunan Ibn Majah juga disyarh oleh al-hafidz 'Alauddin al-Mughalta ib Qolij (w. $762 \mathrm{H}$ ) dan al-hafidz Burhanuddin Ibrahim ibn Muhammad al-halbi Sabat ibn al-'Ajmi ( w. $841 \mathrm{H}$ ), akan tetapi kedua syarh terakhir ini tidak terindentifikasikan namanya.

Syarh terhadap Sunan al-Tirmizi diantaranya adalah Al-'Urfu al-Syaziyyu 'ala Jami' al-Tirmizi karya Syirajuddin Umar ibn Ruslan al-Bulqini al-Syafi'i (w. $805 \mathrm{H}$ ) dan Q-tul al-Mughtazi 'ala Jami al-Tirmizi karya al-hafidz Jalaluddin ibn Abdirrahman ibn Abi Bakar al-Suy-ti (w. 911 H ). Selain kitab tersebut, Sunan al-Tirmizi juga disyarh oleh al-hafidz Abi al-Fath Muhammad ibn Muhammad ibn Sayyid al-Nas (al-Ya'mari ) al-Syafi'i $\quad(w .734 \quad \mathrm{H} \quad) ;{ }^{35}$ Zainuddin Abdurrahman ibn Ahmad ibn al-Nuqaib alhambali (w.?? ), ${ }^{36}$ dan al-hafidz Zainuddin Abdurrahman ibn Ahmad ibn Rajab alHambali (w. 795 H ). ${ }^{37}$

Syarh terhadap Sunan Nasa'i adalah Sunan Nasa'i al-Musamma bi al-Mujtaba karya (syarh ) al-hafidz Jalaluddin ibn Abdirrahman ibn Abi Bakar al-Suyuti (w. $911 \mathrm{H}$ ) dan (hasyiah) dari al-Imam al-Sindi (w. $1038 \mathrm{H} \mathrm{).}{ }^{38}$

Syarh terhadap MuwaTa Imam Malik, diantaranya adalah Kasyfu al-Mughta 'an alMuwaTa (dalam Aujazu: fi Syarh ) alMuwaTa dan Tanwir al-Hawalik 'ala MuwaTa Imam Malik karya al-hafiz Jalaluddin ibn Abdirrahman ibn Abi Bakar al-Suyuti (w. 911 H ) dan Syarh al-Zarqani 1/3 kitab

${ }^{35}$ Kitab Syarhnya tidak selesai, hanya memuat

${ }^{36}$ Kitab Syarh tidak terlacak, karena terbakar dalam peperangan (20 jilid )

${ }^{37}$ Kitab Syarh tidak terlacak. Untuk keterangan catatan kaki no. 23-34 lebih lanjut lihat Al-Maula Mustafa Ibn Abdillah Al-Qustantani Al-Rumi AlHanafi, Juz 2, 441-442.

38 Data fisik terdapat di perpustakaan UIN Alauddin Makassar dengan spesifikasi 8 jilid, penerbit Darul Fikr Beirut, terbit tahun 1995. 'ala Muwata' li Imam Malik ${ }^{39}$ karya Muhammad ibn Abdul Baqi ibn u-suf ibn Ahmad ibn 'Ulwan al-Zarqani al-Misri alMaliki (w. $1122 \mathrm{H}$ ).

Sedangkan usaha pen-syarh-an hadis, pada masa modern (1179 $\mathrm{H}$ hingga sekarang ) diantaranya adalah usaha pensyarahan kitab sahih Muslim oleh Musa Syahin Lasyin (w.2009 M ) dengan judul Fathu al-Mun'im Syarh sahih Muslim. ${ }^{40}$

Syarh Sunan AbuDaud dilakukan oleh alAllamah al-Muhaddis Akabir al-Syaikh alKhalil Ahmad al-Saharanfuri (w. $1346 \mathrm{H}$ ) dikenal dengan Bazlu al-Majh-d fi halli Abi Daud $^{41}$ dan Mahm-d ibn Muhammad ibn KhaTab al-Subki (w $1352 \mathrm{H}$ ) dikenal dengan Al-Manhalu 'Azbu al-Maur-d Syarh Sunan al-Imam Abi Daud. ${ }^{42}$ Dan kemudian AlManhalu 'Azbu dilengkapi oleh Amin ibn Mahm-d ibn Muhammad ibn Ahmad ibn Khitab (w.???) dengan judul Fath al-Malak al-Ma'b-d Tukmilah al-Manhalu 'Azbu alMaur-d Syarh Sunan al-Imam Abi Daud. ${ }^{43}$

Syarh terhadap Sunan Tirmizi pada masa ini diantaranya oleh ibn Abdirrahim alMubarakf-ri (w. 1303 H ) dengan judul Tuhfatu al-Ahwazi. ${ }^{44}$ Syarh terhadap Muwatha Malik oleh al-Dahlawi al-hanafi (w. $1229 \mathrm{H}$ ) dengan judul al-Muhalla bi Asrar al-Muwata. ${ }^{45}$

Selain itu dalam corak fiqh, seperti Subulussalam Syarh Bul-gh al-Maram karya

39 Data fisik terdapat di perpustakaan UIN Alauddin Makassar dengan spesifikasi 4 jilid, penerbit Darul Kutub al-Ilmiyyah Beirut, terbit tahun 1990.

${ }^{40}$ Data kitab Asli Fathu al-Mun'im versi PDF, 10 jilid, cetakan Darul Suruq Mesir, terbit tahun 2002.

41 Data fisik terdapat di perpustakaan UIN Alauddin Makassar dengan spesifikasi 18 jilid, penerbit Darul Fikr Beirut, th.

${ }^{42}$ Data kitab versi PDF dengan spesifikasi 4 jilid, penerbit al-Istiqamah, tahun 1351

${ }^{43}$ Data kitab versi PDF dengan spesifikasi 12 jilid, penerbit Muassasah al-Tarikh al-Arabi Beirut, tahun $1394 \mathrm{H} / 1974 \mathrm{M}$.

44 Data fisik terdapat di perpustakaan UIN Alauddin Makassar dengan spesifikasi 10 jilid, penerbit Darul Fikr Beirut, terbit tahun 1995.

45 Maulana Muhammad Zakaria alKandahlawi, Aujazu al-Masalik ila Muwatta Malik, 51. Untuk data kitab asli Aujazu al-Masalik ila Muwatta Malik karya al-Kandahlawi, cetakan Darul Fikir Beirut, tahun 1980 terdapat di perpustakaan UIN Alauddin Makassar. 
al-Imam Muhammad ibn Ismail al-Amir alsan'ani (w.1182 H ); Nailu al-Autar min Ahadis Sayyid al-Akhyar Syarh Muntaqa alAkhbar karya Muhammad ibn Ali Ibn Muhammad al-Syaukani (w.1172-1255 H ), dan Taisir al-Allam Syarh Umdah al-Ahkam karya Abdullah salih Ali Bassam (w 2002/03 $\mathrm{M})$.

\section{Metode Syarh al-hadis: Antara Klasik,} Pertengahan dan Modern

Mengurai metode yang digunakan oleh para syarih (pen-syarh ), maka penting bagi penulis untuk mengurai pemikiran mufassir dalam menafsirkan al-Qur'an. Melihat kesamaan tujuan dan fungsi antara tafsir dan syarh, maka metode ini memungkinkan dapat menjadi dasar dalam menilai cara kerja dari pensyarahan hadis.

Setidaknya ada empat metode yang dikembangkan dalam ilmu tafsir dalam menafsirkan al-Qur'an, yaitu metode tahlili, ijmali, muqaran, dan maudhu'i. Selain metode di atas, al-Mubarakf-ri dalam Tuhfatu al-Ahwazi ${ }^{46}$ menjelaskan bahwa terdapat 3 cara dalam men-syarh, yaitu al-Syarhu bi Qala Aqulu, al-Syarh bi Qaulihi, al-Syarh Mazjan.

Namun demikian, mengingat keterbatasan waktu, kajian atas metode syarih tidak sepenuhnnya dikaji oleh penulis berdasarkan semua data-data sejarah pen-syarh-an kitab hadis seperti di pembahasan terdahulu. Oleh karena itu, batasan yang penulis sandarkan adalah bahwa penulis hanya mengkaji setidaknya terhadap beberapa kitab di bawah ini, yaitu, Fathu al-Bari Syarh sahih alBukhari, sahih Muslim bi Syarh al-Nawawi (al-Minhaj Syarh Shahih Muslim ), Sunan Nasa'i al-Musamma bi al-Mujtaba, Tuhfatu al-Ahwazi., Ma'alim al-Sunan, Syarh alZarqani 'ala Muwata' li Imam Malik, Fathu al-Mun'im, Hadis-hadis tentang Rukyah alHilal dalam Penetapan awal Bulan Ramadhan dan Syawal karya Prof. Dr. Ambo

\footnotetext{
${ }^{46}$ Abi al-Alla Muhammad Abdurrahman bin Abdurrahim al-Mubarakfuri, Muqaddimah Tuhfatu AlAhwadi, Syarh Jami' Al-Tirmizi (Beirut: Dar al-Fikr, juz. 1, 246-247).
}

Asse, dan Menembus Lailatul Qadar: Perdebatan Interpretasi Hadis Tekstual dan Kontekstual karya Prof. Dr. Muhammadiyah Amin.

Dari 'penjelajahan' atas syarh al-hadis, dan atas sandaran teori metode men-syarh hadis, maka penulis menyimpulkan bahwa syarh yang berkembang, baik pada masa klasik dan pertengahan didominasi oleh metode tahlili, pun demikian pula digunakan oleh pensyarah modern, khususnya Fathul Mun'im karya Musa Yasin Lasyin yang mensyarah sahih Muslim dan Taisir alAllam Syarh Umdah al-Ahkam karya Abdullah salih ${ }^{2}$ li Bassam. Metode yang disajikan oleh para syarih setidaknya tergambar dari beberapa ulasan di bawah ini:

a. Sistematika Penyusunan Menyajikan sesuai dengan kitab yang di-syarh dan mencamtumkan matan dan sanad hadis lengkap.

b. Kajian Sanad:Menjelaskan seluruh rawinya, menjelaskan sebagian rawinya, menjelaskan hanya sebagian kecil rawiyang dianggap asing, menjelaskan nilai al-jarh wa al-wa'dil dan menjelaskan tanda baca dalam nama rawi

c. Kajian Matan; Penjelasan bahasa (kata atau kalimat )penjelasan (nahwiyyat dan sarfiyyat ), penjelasan turuq/jalur lain. penjelasan bahasa gharib (asing), penjelasan Hasil, penjelasan asbab alwurud, penjelasan hukum yang ada, penjelasan pendapat ulama, penjelasan atas hukum (Istimbat hukum )

Khusus untuk metode ijmali pada masa klasik- hanya digunakan al-Khitabi dalam Ma'alim al-Sunan. Hal ini bisa terlihat dari cara pen-syarh-an kitab Sunan Ab- Daud dengan cara menjelaskan hadis-hadis yang terdapat dalam Sunan Abu Daud dengan penjelasan singkat, tanpa memberikan penjelasan baik itu kajian sanad atau matan, ataupun hal yang berkaitan dengan redaksi. Namun demikian, dalam penyajiannya, alKhitabi tetap mengikuti susunan kitab aslinya.

Sedangkan untuk metode maudhu'i banyak digunakan oleh para pen-syarh modern, khususnya dikalangan akademisi di 
perguruan tinggi.Kajian atas karya modern, khususnya di perguruan tinggi berupa tesis dan disertasi terlihat bahwa, kecenderungan yang digunakan dalam men-syarh hadis adalah dengan metode maudhu'i.

\section{SIMPULAN}

Melihat perkembangan syarh terhadap kitab hadis, maka sangat jelas terlihat bahwa kondisi sosial politik dan keagamaan mempengaruhi perkembangan syarh kitab hadis. Setidaknya kecenderungan terhadap satu frame pandangan dalam 'beragama' menjadi faktor pendorong yang tidak terelakan dalam perkembangan syar Oleh karena itu, al-Nadawi menjelaskan bahwa perkembangan syarh hadis terlihat mengikuti alur kecondongan madzhab yang ada, dengan pensyarah-pensyarah yang mempunyai latar belakang madzhab. ${ }^{47}$

Simpulan yang dapat diuraikan atas kajian ini adalah bahwa,

a. Perjalan syarh atas hadis dalam bentuk yang sangat sederhana sudah dimulai sejak masa Rasulullah Saw, dilanjutkan para sahabat hingga tabi'in. Dan usaha pensyarah-an terhadap hadis mendapatkan bentuk yang sempurna pada masa pertengahan (mulai $590 \mathrm{H}$ hingga $1179 \mathrm{H}$ atau $1250 \mathrm{M}-1800 \mathrm{M}$ ).

b. Secara umum, baik periode klasik, pertengahan, hingga modern (mulai dari Abal-hasan Ali ibn Khalaf ibn Abdi al-Malik (w.449 H ) dengan karyanya Syarh sahih alBukhari li Ibn al-BaTal hingga Prof. M-sa Syahin Lasyin (w.2009 M ) dengan karyanya Fathu al-Mun'im ), menggunakan metode tahlili dalam men-syarh kitab hadis. Sedangkan metode ijmali, hanya digunakan oleh Al-Imam Abi Sulaiman hamad ibn Muhammad al-Khitabi al-Busti (w. $388 \mathrm{H}$ ) dalam karyanya Ma'alim al-Sunan.

${ }^{47}$ Al-Nadawi memberikan contoh -dalam kata pengantar Badlu al-Majhid mengatakan bahwa perkembangan syarh yang berkembang di India adalah kitab syarh bermadzhab Hanafi. Oleh karenanya, Badlu al-Majh-d hadir terlepas dari kecondongan yang ada, dan memposisikan pada manhaj ahli hadis. Lebih lanjut lihat Fadilatu al-SyeikhAbi al-Hasan Ali al-Husna Al-Nadaw, Muqaddimah Badlu Al-Majhid Fi Alli Abi Daud (Beirut: Dar al-Kutub al-Ilmiyyah, 1392), 17.
Khusus metode maudhu'i, berkembang dengan sempurna pada pase modern. Model maudhu'i banyak dikembangkan oleh para akademisi di berbagai perguruan tinggi.

\section{DAFTAR PUSTAKA}

Abi al-Alla Muhammad Abdurrahman bin Abdurrahim al-Mubarakfuri, Muqaddimah Tuhfatu Al-Ahwadi, Syarh Jami' Al-Tirmizi (Beirut: Dar al-Fikr)

Afdawiza, Sunan Nasa'i Dalam Studi Kitab Hadis (Yogyakarta: Teras, 2003)

Al-Bukhori, Muhammad bin Isma'il Abu Abdullah, Al-Jami' Al-Shohih Al-Bukhori Al-Mukhtasar, ed. by Musthafa Dib (Beirut: Darr Ibnu Katsir, 1987)

Al-Masriy, Muhammad bin Mukrim bin Mundzir al-Afriqiy, Lisan Al-Arab (Beirut: Darr cadr)

Al-Maula Mustafa ibn Abdillah al-Qustantani alRumi al-Hanafi, Kasyfu Al-Fun-n 'an Asami Al-Kutub Wa Al-Funun (Beirut: Dar al-Fikr, 1994)

Al-Nadaw, Abi al-Hasan Ali al-Husna, Muqaddimah Badlu Al-Majhid Fi Alli Abi Daud (Beirut: Dar al-Kutub al-Ilmiyyah, 1392)

Dadi Nurhaedi, SahihMuslim Dalam Studi Kitab Hadis (Yogyakarta: Teras, 2003)

Indal Abror, Kitab Al-Sahihal-Bukhari, Dalam Studi Kitab Hadis (Yogyakarta: Teras, 2003)

M. Alfatih Suryadilaga, Sunan Ibn Majah Dalam Studi Kitab Hadis (Yogyakarta: Teras, 2003)

Maulana Muhammad Zakaria al-Kandahlawi, Aujazu Al-Masalik Ila Muwatta Malik (Beirut: Dar al-Fikr)

Mo Isom Yoesq, Inklusivitas Hadits Nabi Muhammad Saw Menurut Ibn Taimiyah (Jakarta: Pustaka Mapan, 2006)

Muhammad Muhammad Abu Syuhbah, Fi Rihab Al-Sunnah: Al-Kutub Al-Sahhah Al-Sittah (kairo: Majmu al-Buhus al-Islami, 1969)

Muhammad Mustafa Azhami, Hadis Nabawi Dan Sejarah Kodifikasinya (Jakarta: Pustaka Firdaus, 1994)

Muslim ibn al-Hajjaj, Al-Dibaj 'ala Sahih Muslim Ibn Al-Hajjaj (Saudi Arabia: Dar ibn 'Affan, 1996)

Saifuddin, Tadwin Al-Hadis: Kontribusinya Dalam Perkembangan Historiografi Islam (Banjarmasin: Antasari Press, 2008)

Shalih, Subhi, Ulum Al-Hadits Wa Musthalahuhu (Beirut: Dar Al-Ilmu Li al-Malayin, 1988) 
Suryadi, Jami' Al-Tirmidzi Dalam Studi Kitab Hadis (Yogyakarta: Teras, 2003)

_, Sunan Abu Daud Dalam Studi Kitab Hadis (Yogyakarta: Teras, 2003)

Zakaria, Abi al-Husain Ahmad Faris bin, Mu'jam
Al-Maqayis Fi Al-Lughah, ed. by Abdussalam Muhammad Harun (Beirut: Darr al-Fikr, 1979) 
